\title{
Effects of clenbuterol therapy on mitochondrial activity in skeletal musculature of RAO affected horses
}

\author{
Heidrun Gehlen', Christina Stave'2, Thomas Bilzer ${ }^{3}$ and Peter Stadler ${ }^{2}$ \\ 1 Equine Clinic, Free University of Berlin, Germany \\ ${ }^{2}$ Clinic for Horses, University of Veterinary Medicine Hannover, Germany \\ ${ }^{3}$ Department of Neuropathology, Heinrich-Heine-University Düsseldorf, Germany
}

\begin{abstract}
Summary: Chronic pulmonary disease alters skeletal muscle in humans and horses. The purpose of this study was to evaluate a possible effect of the B2-sympathomimetic agent clenbuterol, known for its bronchodilatory and anabolic effects on skeletal musculature, on mitochondrial activity and histopathologic changes of skeletal musculature horses suffering from recurrent airway obstruction (RAO). We hypothesized that clenbuterol treatment has an effect on mitochondrial activity and histopathologic changes of RAO patients. Therefore 14 healthy horses (control) and 18 RAO patients without primary muscle disease were examined in a prospective clinical trial. In all horses a complete lung examination was performed. All horses received clenbuterol at a dosage of $0.8 \mu \mathrm{g} / \mathrm{kg}$ BDW bid for 2 intervals of 12 days and a 4-day-break. Muscle enzymes and muscle biopsies (M. gluteus medius) were examined histologically and histochemically at rest and $24 \mathrm{~h}$ after exercise before and after clenbuterol treatment. Clinical, laboratory and histopathologic examination of skeletal muscle samples excluded primary myopathies in all horses. A significant increase of mitochondrial activity was found in RAO patients compared to healthy controls. A significant reduction in mitochondrial activity was obvious after clenbuterol application in RAO patients. An effect of standardized exercise on mitochondrial activity in skeletal musculature could not be found. In conclusion clenbuterol therapy reduces skeletal muscle changes in RAO patients.
\end{abstract}

Keywords: RAO, skeletal muscle, exercise, muscle biopsy, histopathology, mitochondrial activity

Untersuchung der Skelettmuskulatur bei chronisch lungenkranken Pferden vor und nach Therapie mit Clenbuterol und vor und nach Belastung

Die Chronische Lungenerkrankung beeinträchtigt den Skelettmuskel beim Menschen und beim Pferd. Ziel der Studie war die Untersuchung eines möglichen Effekts des $\beta 2$-sympathomimetischen Wirkstoffs Clenbuterol auf die Mitochondrienaktivität und histopathologische Veränderungen im Skelettmuskel von Pferden, die an RAO leiden. Im Rahmen dieser Studie wurden 18 an RAO erkrankte Pferde und 14 gesunde Kontrolltiere untersucht. Es wurden Stanzbioptate aus dem Muskulus glutaeus medius vor und nach Belastung, sowie vor und nach einer 24-tägigen Verabreichung von Clenbuterol untersucht. Clenbuterol wurde in einer Dosierung von 0,8 $\mu \mathrm{g} / \mathrm{kg}$ zweimal täglich per oral verabreicht, wobei nach zwölf Tagen eine viertägige Medikationspause eingelegt wurde. Die histopathologische Auswertung der Muskelproben zeigte eine erhöhte mitochondriale Aktivität, ähnlich den Ragged-Red-Fasern des Menschen. Bei zwölf Pferden, welche diese Veränderungen aufwiesen, zeigte sich in der Kontrolluntersuchung nach Clenbuterolverabreichung eine Reduktion der mitochondrialen Aktivität. Die Untersuchung der Skelettmuskulatur vor und nach Belastung lieferte keine einheitlichen Ergebnisse. Somit konnte keine direkte Auswirkung einer standardisierten Belastung auf die mitochondriale Aktivität in dieser Studie nachgewiesen werden.

Schlüsselwörter: RAO / Skelettmuskel / Belastung / Muskelbiopsie / Histopathologie / Mitochondrien / Aktivität

Citation: Gehlen H., Stave C., Bilzer T., Stadler P. (2015) Effects of clenbuterol therapy on mitochondrial activity in skeletal musculature of RAO affected horses. Pferdeheilkunde 31, 4-11

Correspondence: Heidrun Gehlen, Prof. Dr., Dipl ECEIM, Equine Clinic, Free University of Berlin, Oertzenweg 19b, 14063 Berlin, Email: Heidrun.gehlen@fu-berlin.de

\section{Introduction}

For about 15 years, the effects of chronic obstructive pulmonary disease (COPD) on skeletal muscle have been studied in men. Respiratory disease has been shown to induce a reduction in muscle mass, strength and endurance. In several studies, histopathologic alterations of various degrees were found including muscle fiber atrophy, caliber changes and variations in mitochondrial enzyme profiles (Bernhard et al. 1998, Engel and Franzini-Armstrong 1994, Gosselink et al. 1996 and 2000, Jerusalem and Ziers 2003, Kim et al. 2008).

Additional exercise-induced pathological alterations were found in COPD patients, namely increased oxidation of fatty acids and proteins (Gosselink et al. 1996, Berhard et al. 1998, Gosselink et al. 2000, Kim et al. 2008). In equine medicine, histologic examinations on skeletal muscle have traditionally been performed in cases of myopathies and to study exercise physiology. Gehlen et al. (2008) found skeletal muscle changes in horses affected by chronic respiratory disease, which included structural changes in muscle fiber caliber and fiber type and also increased mitochondrial activity characterized by "ragged-red-like fibers". These fibers show typical fuchsin-red borders using Gomori-Trichrom-staining, which are a consequence of prominent membranous depositions in the subsarcolemma and between myofibers. In humans this membranous material consists of accumulated hyperplastic mitochondria and seems to be a consequence of oxidative stress and disturbed oxidative phosphorylation (Jerusalem and Ziers 2003). Often, the endomysial texture appears fragmented or disrupted, and shows beginning fibrosis. 
While several therapeutic approaches have been developed in human medicine to inhibit muscle catabolism and structural changes of skeletal muscle (Maltais et al. 1996, Whittom et al. 1998, O'Donnell et al. 2007, Seemungal et al. 2009), no studies have been performed in horses affected by RAO. This very common equine disease features some characteristics of COPD in men.

The aim of this study was to evaluate the effects of a 4 week clenbuterol treatment on skeletal muscle in RAO patients in comparison to healthy controls. The $B 2$-sympathomimetic agent clenbuterol is commonly used in RAO therapy to achieve bronchospasmolysis (Carlos and Davis 2007). Apart from its bronchodilatory effect clenbuterol shows anabolic effects on muscle tissue and reduces the percentage of adipose tissue, which is called repartitioning. This is due to the fact that sympathomimetic agents inhibit fatty acid synthesis and induce lipolysis (Kearns et al. 2001, Löscher et al. 2003), but these effects have been described for much higher dosages than what is recommended for RAO therapy. We hypothesized that metabolic skeletal muscle alterations can be reduced by increased respiratory function and improved tissue oxygenation. Additionally, the effects of standardized exercise on skeletal muscle were to be examined in RAO horses before and after clenbuterol treatment.

\section{Material and Methods}

Animals

18 RAO-affected horses (10 geldings, 6 mares, 2 stallions; mean age: $13 \pm 6$ years; mean body weight: $563 \pm 75 \mathrm{~kg}$, mean height: $166 \pm 5 \mathrm{~cm}$ ) affected by RAO (16 warmbloods, 2 trotters) and 14 healthy controls (8 warmbloods, 4 trotters, 2 thoroughbreds) were included in the study. The RAO patients had a history of chronic and recurrent clinical signs of RAO, but no history of musculoskeletal disease. Most RAO horses $(n=15 / 18)$ and all of the healthy controls were not exercised regularly every day for weeks to month before examination (untrained).

All horses were studied under the same environmental conditions. They were kept in separate paddocks, received wood shavings as bedding and wet hay as roughage, and had been stabled under these conditions for at least two weeks before clenbuterol application. None of the horses had received any medical treatment for 6 weeks prior to the study, which was subjected to ethical guidelines of the veterinary university, Hannover. For the RAO horses admitted to the equine clinic, informed consent of the owner was obtained.

\section{Lung Examination}

The lung examination included history, auscultation, arterial blood gas analysis (ABG), endoscopic examination, cytological evaluation of tracheo-bronchial secretions (TBS) and broncho-alveolar lavage fluid as well as radiographic examination. The diagnosis of RAO was based on more than one typical clinical sign (dyspnea at rest, tachypnoea, chronic/recurrent cough, prolonged in- and/or expiration), artrio-alveolar-oxygen-difference $\left(\mathrm{AaDO}_{2}\right)>7 \mathrm{mmHg}$ in
$A B G$, increased tracheal secretion and thickened tracheal septum, cytology dominated by neutrophils in cell count of tracheobronchial secret (TBS) and broncho-alveolar lavage (BAL) analysis, Curshmann 's spirals in TBS and peribronchial infiltrations visible on radiographs. According to the clinical and endoscopical findings the horses were divided into 3 groups: mild, moderate and severe RAO (Ohnesorge et al. 1998, 1998a).

\section{Exercise test}

Muscle specific enzymes creatine kinase, aspartate aminotransferase, lactate dehydrogenase and the lactate value were determined before and after $(0,4$ and 24 hours post exercise) a standardized lounging exercise test $(10 \mathrm{~min}$ walk, 10 min trott, 5 min canter). Horses with abnormal findings of any of the above parameters were excluded from this study because of the potential presence of primary muscle disease.

\section{Muscle biopsies}

Three days after the exercise test muscle biopsies were removed from the right $M$. glutaeus medius by using a Bergström muscle biopsy punch under sedation with detomidine ${ }^{a}$ $(0.01-0.1 \mathrm{mg} / \mathrm{kg}$ i.v.). Samples were taken at a depth of $50-80 \mathrm{~mm}$ from the skin surface. The muscle biopsies were placed in a sterile tube, stored at $4{ }^{\circ} \mathrm{C}$ and transported within 24 hours for histopathological diagnosis to the laboratory ${ }^{b}$.

\section{Histological examinations}

In the laboratory the muscle biopsies were freed of fat and fascia, embedded in tragant and frozen during 20 to 30 seconds in isopentane $\left(-135^{\circ} \mathrm{C}\right)$ precooled in liquid nitrogen. Sections were air-dried, acetone-fixed at $-20^{\circ} \mathrm{C}$ for 10 minutes, and then stained with haematoxilin-eosin (HE) and using the Gomori-trichrome staining, which enables visualization particularly of myofibrillar and mitochondrial changes (visible as a red limb) of muscle cells.

The muscle samples were reacted with NADH-tetrazoliumreductase combined with ATPase reactions between 9.4 and 9.6, in order to determine the muscle fibre typing (type 1 and $2)$, as well as fiber-type-specific alterations and fiber-type groupings. Oil-red-staining was used to evaluate any endomysial and interstitial pathological fat storage. The acid phosphatase stain was used to monitor the presence of pathological enzyme activity indicating cell necrosis. For identification of structure and content of polysaccharides in the sarcoplasma, Periodic Acid Schiff (PAS) staining was performed, whereby muscle sections were cut in pairs, and one section was pre-treated with diastase. Diastase-resistance is a good indicator of polysaccharides metabolic diseases, e.g. PSSM. All muscle biopsies were examined microscopically at various magnifications from 2.5 up to 40 fold by two independent and blinded investigators.

A semi-quantitative analysis was performed by scoring the frequency of the histological and histochemical findings, especially the mitochondrial activation and/or -hyperplasia 
visible as subsarcolemmal red rims in the Gomori trichrome stained sections $(0=$ not visible, $1=$ isolated, $2=$ multiple, $3=$ frequent visible). The scoring of mitochondrial activation was compared between control and RAO-group before and after treatment. Muscle cell glycogen content was scored ( $0=$ regular glycogen content, $1=$ no glycogen visible) .

\section{Clenbuterol treatment}

RAO patients and healthy controls received clenbuterolhydrochloride (Ventipulmin ${ }^{\mathrm{TM}}$ ) $^{\mathrm{C}}$ for two 12-day-periods at a dosage of $0.8 \mu \mathrm{g} / \mathrm{kg}$ BDW BID orally. In between treatment period 4 days without treatment were included in the study protocol to avoid tachyphylaxis of 32 -adrenoceptors. Following the treatment period a second examination of the respiratory system and the musculature was performed. The procedure was equivalent to the first examination.

\section{Statistics}

Analyses were carried out with the statistical software SAS, version 9.1. ${ }^{d}$ The Friedmann test for paired samples and the Wilcoxon test for non parametric independent samples were used for the results of the histopathologic examination of skeletal muscle before and after clenbuterol application. $\mathrm{P}<0.01$ was considered to be significant in all tests.

\section{Results}

\section{Results of the lung examination}

All 18 RAO patients had a history of recurrent respiratory problems of more than 4 months duration. Clinical examination revealed an increased respiratory rate at rest $(n=11)$, audible crackles and wheezes during thoracic auscultation $(n=18)$, mucous nasal discharge $(n=6)$ and spontaneous coughing $(n=14)$. The mean arterial partial oxygen pressure $\left(\mathrm{PaO}_{2}\right)$ was $85 \mathrm{mmHg}$ and the mean arterio-alveolar oxygen pressure difference $\left(\mathrm{AaDO}_{2}\right)$ was $19.3 \mathrm{mmHg}$. Endoscopy revealed an increased amount and viscosity of tracheal secretions $(n=18)$ and a thickened bifurcatio tracheae $(n=18)$. Tracheo-bronchial secrete analysis identified $>25 \%$ neutrophils $(n=18)$ and curshmann's spirals $(n=12)$. BAL-fluid contained 28-39\% neutrophils. Radiography revealed broncho-

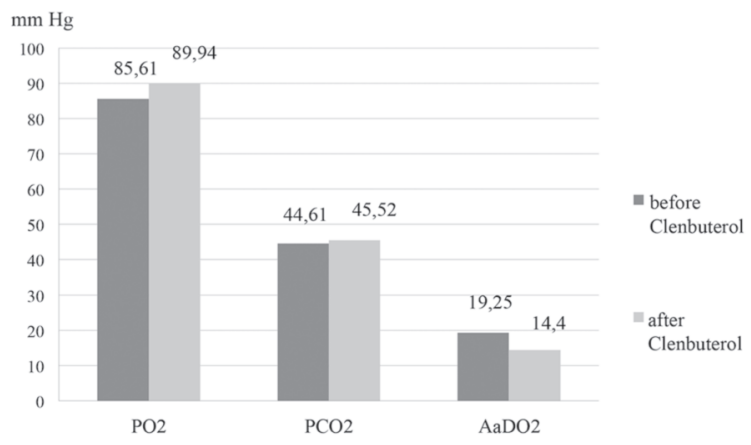

Fig. 1 Mean values of blood gas analysis before and after clenbuterol application. $\mathrm{PO}^{2}=$ partial oxygen pressure gradient, $\mathrm{PCO}^{2}=$ partial carbon dioxide pressure gradient, $\mathrm{AaDO}^{2}=$ arterioalveolar-oxygen-difference. interstitial patterns $(n=14)$ and bronchiectasis $(n=18)$. All 18 horses were diagnosed with recurrent airway obstruction (RAO). According to the severity of pulmonary findings 3 horses suffered from mild RAO, 5 horses from moderate RAO and 10 horses showed severe RAO.

After clenbuterol application the severity of pulmonary findings decreased 5 horses suffered from mild RAO, 6 horses from moderate RAO and 5 horses showed severe RAO, while in 2 horses the pulmonary findings were nearly in physiological ranges). Especially $\mathrm{PaO}_{2}$ and $\mathrm{AaDO}_{2}$ increased after therapy (fig. 1). All 14 controls were found to be free of respiratory disease before and after treatment.

\section{Results of the exercise test}

Before and after treatment four RAO horses were not able to complete the exercise test. Neither the control nor the RAOhorses showed a pathological increase of muscular enzymes at rest or after exercise. Lactate values before, $4 \mathrm{~h}$ and $24 \mathrm{~h}$ after exercise were in normal ranges between 0.2 und 1.9 $\mathrm{mmol} / \mathrm{L}$. Immidiatly after exercise lactate values up to 5.8 $\mathrm{mmol} / \mathrm{L}$ (mean $1.4 \pm 1.2 \mathrm{mmol} / \mathrm{L}$ ) were measured.

\section{Histopathology}

No complications were noted after the muscle biopsy and none of the horses was diagnosed with signs of a primary myopathy according to histopathological examinations. In 8

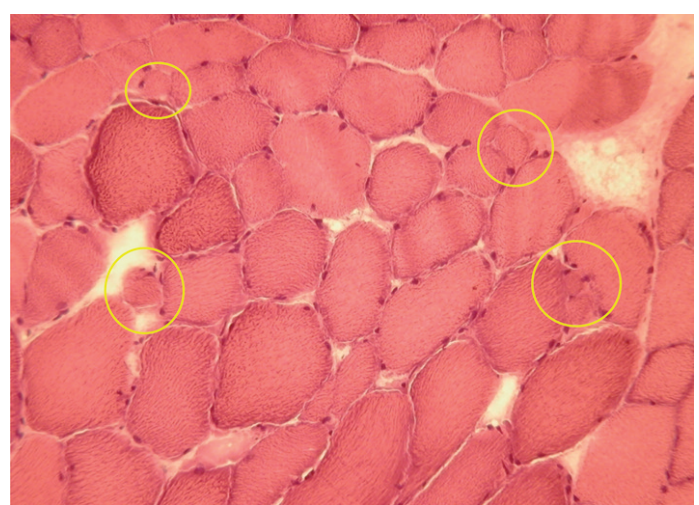

Fig. 2 Skeletal musculature (M. gluteaus medius) of a horse suffering from RAO with increased muscle fiber caliber variation (H.E.Staining).

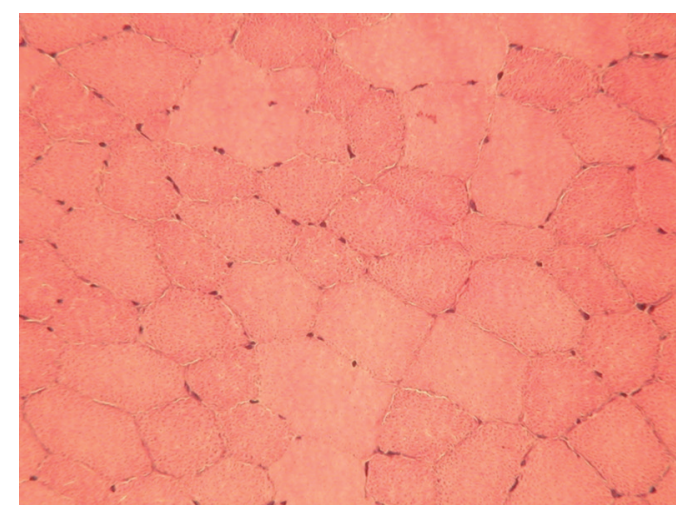

Fig. 3 Skeletal musculature (M. gluteaus medius) of a RAO horse after clenbuterol therapy with regular muscle fiber calibers (H.E.-Staining). 
of the 18 RAO horses moderate bimodal pathological muscle fibre caliber variations (atrophies and hypertrophies) were found (fig. 2). After clenbuterol treatment the muscle fiber calibre spectrum had normalized (fig. 3).

Before treatment nearly all of the RAO patients (17/18) showed mitochondrial hyperplasia/activation in many muscle

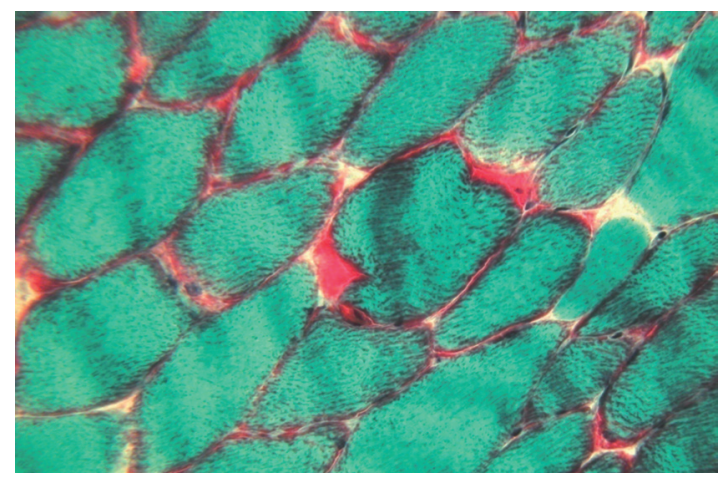

Fig. 4 Skeletal musculature of a horse suffering from RAO showing increased mitochondrial hyperplasia documented by red cell borders (Gomori-Trichrome-Staining).

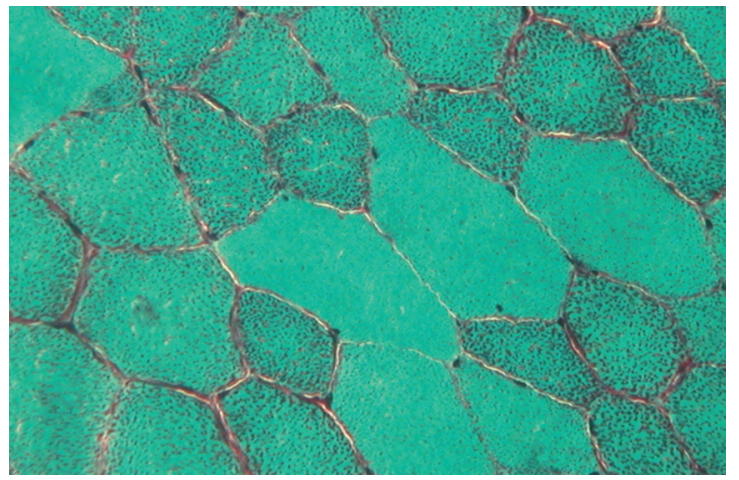

Fig. 5 Skeletal musculature of a horse free of respiratory disease (control) without pathologic alterations (Gomori-Trichrom-Staining).

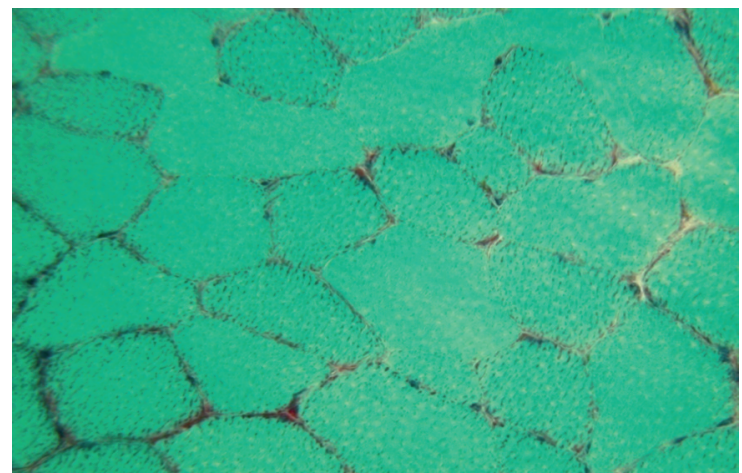

Fig. 6 Skeletal musculature (M. glutaeus medius) of an RAO affected horse displaying normal mitochondrial acitvity after clenbuterol treatment (Gomori-Trichrome-Staining), same horse as in figure 4. fibers (table 1, figure 4). The mitochondrial activation in RAO horses was significantly higher than in the control group $(P=0.006$; mean score value healthy $=0.7$ versus $R A O=1.5$; fig 4 and 5). After exercise in both groups no significant differences of mitochondrial activation could be observed compared to the examination at rest.

After clenbuterol treatment the mitochondrial activation in the RAO-group was significantly decreased $(P=0.015$; mean score value healthy $=0.4$ versus $\mathrm{RAO}=0.8$, fig 6). After exercise and after clenbuterol treatment also no significant differences of mitochondrial activation could be observed compared to the examination at rest in none of the groups.

\section{Histochemistry}

None of the horses showed increased or irregular fat storage, increased activity of acidic phosphotase (indicating cell necrosis and/or degeneration) or accumulation of diastaseresistant polysaccharides. After clenbuterol treatment no histochemical changes were found either.

\section{Discussion}

In a previous study significant structural skeletal muscle changes were demonstrated in RAO affected horses in comparison to healthy controls (Gehlen et al. 2008). At this time it was not known, whether these changes can be influenced by pharmacological treatment. In the present study possible effects of clenbuterol on the microstructure of the skeletal musculature have been examined in horses suffering from chronic respiratory disease (RAO).

Muscular changes secondary to COPD have been described in men as metabolic and structural alterations in the mitochondria. Remels et al. (2007) suspected a reduced mitochondrial biogenesis in COPD patients. An increase in TNF- $\alpha$ was found, which could affect mitochondrial biogenesis (Valerio et al. 2008). Additionally, a switch from type1 -fibres to glycolytic type-2-fibres was found, the later showing earlier signs of fatigue. This seems to be a consequence of reduced oxidative capacity caused by a reduced mitochondrial density (Gosker et al. 2002, Gosker et al. 2007a, Gosker 2007b).

The authors of several studies in horses have suspected a possible interaction between a reduced gas exchange and the skeletal musculature and suggested that an imbalance in anti-oxidative capacity may cause structural skeletal muscle changes in RAO patients (Gosker 2007b, Kirschvink et al. 2003, Kirschvink et al. 2002).

\begin{tabular}{|c|c|c|c|c|}
\hline & \multicolumn{4}{|c|}{ Mitochondrial activity } \\
\hline & no increases (score 0) & mild increase (score 1) & moderate increase (score 2) & severe increase (score 3) \\
\hline RAO before therapy & 1 & 8 & 8 & 1 \\
\hline RAO after therapy & 4 & 13 & 1 & 0 \\
\hline Control before therapy & 4 & 8 & 2 & 0 \\
\hline Control after therapy & 8 & 6 & 0 & 0 \\
\hline
\end{tabular}




\section{Effect of therapy}

In human COPD patient successful therapy of respiratory disease led to reduced or even diminished mitochondrial enzymatic deferments and it was the aim of this study to evaluate this in horses suffering from chronic airway disease. Horses affected with RAO are commonly treated with glucocorticoids and $\beta 2$-mimetic agents. The effects and long-term effects of these medications on the skeletal musculature in the horse are not completely understood. Clenbuterol is known to induce different structural changes in skeletal muscle (Kearns et al. 2002, Kearns et al. 2001). An increased blood supply, an improved oxygen metabolism muscle and a direct anabolic effect of $\beta 2$-mimetic agents has been found in human muscle and with a high probability also in equine muscle. In contrast, glucocorticoids exert a catabolic effect. Although clenbuterol has been shown to increase lung function in several studies (Kearns et al. 2002, Kearns et al. 2001), a direct effect on the mitochondria can be suspected. According to our results, mitochondrial hyperplasia/acitivity was obviously reduced by clenbuterol, although respiratory function did not increase in most horses. In rats, 14 days of clenbuterol treatment led to increased muscle mass and protein content. In fast muscle fibers the optic density of mitochondria was reduced by $20 \%$ and the glycogen content was reduced by $30 \%$ in comparison to controls (Burniston et al. 2007).

\section{Influence of training}

Studies in men demonstrated an influence of training on muscle tissue in individuals affected by respiratory disease (Whittom et al. 1998). Special endurance training led to reduction or even compensation of skeletal muscle changes in COPD patients (Whittom et al. 1998). Chronic inactivity also causes adaptive changes in human skeletal muscle. The portion of type 1 muscle fibers is reduced, muscle fiber atrophy, reduced capillary density and a reduced content of antioxidative enzymes occur. The severity of these changes depends largely on cause and duration of inactivity. In comparison to healthy individuals the skeletal musculature of COPD patients seems to be affected to a higher degree by chronic inactivity (Covillard et al. 2003). In the presented study, the horses were not in regular training, but were also not completely inactive. Unfourtunatly it was not possible to compare trained and untrained RAO horses, due to the fact that most RAO horses could only be reduced exercised. A possible influence of training on mitochondrial activity cannot be excluded at this time.

\section{Influence of other factors}

An influence of age, gender and breed on mitochondrial activity may also be possible. The percentage of ragged red fibers increases with age in men, so a small percentage is considered physiological in elderly patients. To increase the homogeneity of the studied subjects, mainly warmbloods were used in our study. Mares, geldings and stallions of all ages were included and no differences in mitochondrial activity were found in correlation to age or gender. Therefore, these factors could be excluded to increase mitochondrial activity.

\section{Conclusion}

In conclusion, the results of the presented study show that increased mitochondrial activity in RAO affected horses can be influenced by clenbuterol treatment. After therapy, a significant reduction in mitochondrial activity was found in RAO patients, but not in healthy controls. This reduction was obvious independent of increased respiratory function, as only two patients showed improved lung function after treatment. Therefore, clenbuterol seems to have a direct effect on mitochondrial activity, which is not a consequence of increased oxygenation in the musculature after respiratory improvement. Early and consequent therapy of skeletal muscle changes is likely to improve the metabolic function of the musculature in sports horses, increasing their endurance and dynamic capacity. In further studies, the long-term effects of clenbuterol treatment should be evaluated to find out, whether one course of therapy is effective or if repetitive treatments are required.

\section{Footnotes}

a Domosedan ${ }^{\circledR}$, Pfizer Tiergesundheit, Karlsruhe, Germany

b Department of Neuropathology, University of Düsseldorf., Germany

${ }^{c}$ Ventipulmin ${ }^{\circledR}$, Boehringer Ingelheim, Ingelheim, Germany ${ }^{d}$ SAS Institute, Cary, NC, U.S.A

\section{Acknoledgement}

Ventipulmin was provided at no charge for this study by Boehringer Ingelheim, Ingelheim, Deutschland.

\section{Conflict of Interest statement}

The authors exclude any conflict of interest.

\section{List of abbreviations}

$\mathrm{AaDO}_{2}$ Arterio-alveolar-oxygen-difference

ABG Arterial blood gas analysis

ATP Adenosintriphosphate

BAL Broncho-alveolar lavage

COPD Chronic obstructive pulmonary disease

HE haematoxilin-eosin

$\mathrm{NADH}$ reduced form of nicotinamide-adenine-dinucleotide

PAS Periodic acid Schiff

RAO Recurrent airway obstruction

TBS Tracheobronchial secret

\section{References}

Bernard S., Leblanc P., Whittom F., Carrier G., Jobin J., Belleau R., Maltais F. (1998) Peripheral muscle weakness in patients with chronic obstructive pulmonary disease. Am. J. Respir. Crit. Care Med. 158, 629-634

Burniston J. G., McLean L., Beynon R. J., Goldspink D. F. (2007) Anabolic effects of a non-myotoxic dose of the $\beta 2$-adrenergic receptor agonist clenbuterol on rat plantaris muscle. Muscle Nerve $35,217-223$ 
Carlos L., Davis M. (2007) Does clenbuterol positively affect racing horses. Equine Vet. Educ. 19, 228-230

Couillard A., Maltais F., Saey D., Debigare R., Michaud A., Koechlin C., Leblanc P., Prefaut C. (2003) Exercise-induced quadriceps oxidative stress and peripheral muscle dysfunction in patients with chronic obstructive pulmonary disease. Am. J. Respir. Crit. Care Med. 67, 1664-1669

Gehlen H., Oey L., Rohn K., Bilzer T., Stadler P. (2008) Pulmonary dysfunction and skeletal muscle changes in horses with RAO. J. Vet. Int. Med. 22, 1014-1021

Gosker H. R., Van Mameren H., Van Dijk P. J., Engelen M. P., Van der Vusse G. J., Wouters E. F., Schols A. M. (2002) Skeletal muscle fibre-type shifting and metabolic profile in patients with chronic obstructive pulmonary disease. Eur. Respir. J. 19.617-625

Gosker H. R., Hesselink M. K., Duimel H., Ward K. A., Schols A. M. (2007) Reduced mitochondrial density in the vastus lateralis muscle of patients with COPD. Eur. Respir. J. 30, 73-79

Gosker H. R., Zeegers M. P., Wouters E. F., Schols A. M. (2007) Muscle fibre type shifting in the vastus lateralis of patients with COPD is associated with disease severity: a systematic review and metaanalysis. Thorax 62, 944-949

Gosselink R., Troosters T., Decramer M. (1996) Peripheral muscle weakness contributes to exercise limitation in COPD. Am. J. Respir Crit. Care Med. 153, 976-980

Gosselink R., Troosters T., Decramer M. (2000) Distribution of muscle weakness in patients with stable chronic obstructive pulmonary disease. J. Cardiopulm. Rehabil. .20, 353-360

Kearns C. F., McKeever K. H., Malinowski K.,. Struck M. B., Abe T. (2001) Chronic administration of therapeutic levels of clenbuterol acts as a repartitioning agent. J. Appl. Physiol.91, 2064-2070

Kearns C. F., McKeever K. H. (2002) Clenbuterol diminishes aerobic performance in horses. Med. Sci. sSports. Exerc. 34, 1976-1985.

Kim H. C., Mofarrahi M., Hussain S. N. (2008) Skeletal muscle dysfunction in patients with chronic obstructive pulmonary disease. Int. J. Chron. Obstruct. Pulm. Dis. 3, 637-658

Kirschvink N., Fievel L., Bougnet V., Art T., Degand G., Smith N., Marlin D., Roberts C., Harris P., Lekeux P. (2003) Effect of nutritional antioxidant supplementation on systemic and pulmonary antioxidant status, airway inflammation and lung function in heavesaffected horses. Equine Vet. J. 34, 705-712

Kirschvink N., Smith N., Fievel L., Bougnet V., Art T., Degand G. Marlin D., Roberts C., Genicot B., Lindsay P., Lekeux P. (2002) Effect of chronic airway inflammation and exercise on pulmonary and systemic antioxidant status of healthy and heaves-affected horses. Equine Vet. J. 34, 563-571

Maltais F., Simard A. A., Simard C., Jobin J., Desagnes P., Leblanc P. (1996) Oxidative capacity of the skeletal muscle and lactic acid kinetics during exercise in normal subjects and in patients with COPD. Am. J. Respir. Crit. Care Med. 153, 288-293

Ohnesorge B., Trötschel C., Deegen E. (1998) Bestimmung von Totraum und exspiratorischem Mischluftvolumen zur Diagnostik chronischer Lungenerkrankungen beim Pferd. Pferdeheilkunde 14, 450-455

Ohnesorge B., Trötschel C., Deegen E. (1998) Diagnostic value of capnography in horses with RAO. Proceedings 5th World Equine Vet. Assoc. Congress, 65-69

Remels A. H., Schrauwen P., Bkroekhuizen R., Willems J., Kersten S., Gosker H. R., Schols A. M. (2007) Peroxisome proliferator-activated receptor expression is reduced in skeletal muscle in COPD. Eur. Respir. J. 30, 245-252

Seemungal T. A., Hurst J. R., Wedzicha J. A. (2009) Exacerbation rate, health status and mortality in COPD - a review of potential interventions. Int. Chron. Obstruct. Pulm. Dis. 4, 203-223

Valerio A., Cardile A., Cozzi V., Bracale R., Tedesco L., Pisconti A., Palomba L., Cantoni O., Clementi E., Moncada S., Carruba M. O., Nisoli E. (2008) TNF-alpha downregulates eNOS expression and mitochondrial biogenesis in fat and muscle of obese rodents. Clin. Invest. 1 16, 2791-2798

Van Helvoort H. A., Heijdra Y. F., de Boer R. C., Swinkels A., Thiis H. M., Dekhuiizen P. N. (2007) Six-minute walking-induced systemic inflammation and oxidative stress in muscle-wasted COPD patients. Chest 131, 439-445
Whittom F., Jobin J., Simard P. M., Leblanc P., Simard C., Bernard S., Belleau R., Maltais F. (1998) Histochemical and morphological characteristics of the vastus lateralis muscle in patients with chronic obstructive pulmonary disease. Med. Sci. Sports Exerc. 30, 1467-1474

Erweiterte Zusammenfassung

Seit ca. 15 Jahren werden in der Humanmedizin Auswirkungen chronisch obstruktiver Lungenerkrankungen auf die Skelettmuskulatur untersucht. Dabei wird insbesondere ein Abbau der Muskelmasse, eine reduzierte Muskelkraft und Muskelausdaver beobachtet. In zahlreichen Studien konnten darüber hinaus histologische Veränderungen in der Muskulatur verschiedenen Ausmaßes nachgewiesen werden. Diese äußern sich in Form von Muskelfaseratrophien, Muskelfaserkaliberveränderungen und Variationen der mitochondrialen Enzymprofile

In einer Studie von Gehlen et al. (2008) wurden erstmalig Veränderungen in der Skelettmuskulatur auch bei chronisch lungenkranken Pferden nachgewiesen, die bei gesunden Kontrolltieren so nicht beobachtet wurden. Die strukturellen Veränderungen äußern sich in Form von Muskelfaserkaliberveränderungen, Fasertypverschiebungen und in einer erhöhten mitochondrialen Aktivität in Form von "ragged-red"-ähnlichen Fasern. "Ragged-red"-Fasern äußern sich in der modifizierten Gomori-Trichrom-Färbung als Muskelzellen mit charakteristischen fuchsinroten Randsäumen.

Während es in der Humanmedizin bereits verschiedene therapeutische Ansätze gibt, um dem Muskelkatabolismus und den strukturellen Veränderungen in der Skelettmuskulatur entgegenzuwirken, ist in der Veterinärmedizin bislang noch nicht untersucht worden, ob und in wie weit sich diese Skelettmuskelveränderungen bei erkrankten Pferden therapeutisch beeinflussen lassen. Deshalb sollte in dieser Studie evaluiert werden, ob und auf welche Art eine vierwöchige Therapie mit einem 2-Sympatomimetikum (Clenbuterol) die genannten Veränderungen in der Skelettmuskulatur beeinflussen kann. Die Ausgangsthese dieser Studie war es, durch eine Verbesserung der Lungenfunktion nach medikamenteller Behandlung eine Reduktion der metabolischen Skelettmuskelveränderungen zu erreichen.

Im Rahmen dieser Studie wurden deshalb 18 RAO erkrankte Pferde und 14 Kontrolltiere untersucht. Bei allen Pferden wurden neben einer klinischen Allgemeinuntersuchung, eine arterielle Blutgasanalyse, eine bronchoskopische Untersuchung inklusive Gewinnung und Untersuchung von Tracheobronchialsekret, eine bronchoalveoläre Lavage und eine röntgenologische Untersuchung der Lunge durchgeführt. Die Klassifizierung und Einstufung des Schweregrades der Lungenerkrankung erfolgte nach einem in der Klinik routinemäBig zur Diagnostik von chronischen Pneumopathien verwendeten Score- System nach Ohnesorge et al. (1998). Um primäre Myopathien auszuschließen, wurde im Rahmen einer standardisierten Belastung an der Longe eine Verlaufsuntersuchung der Muskelenzyme Creatinkinase (CK), Aspartat-Amino-Transferase (AST), Laktatdehydrogenase (LDH) und des Laktatwertes im Blut durchgeführt.

Die Muskelbiopsien erfolgte am sedierten Pferd mittels der Muskelbiopsiestanze nach Bergström aus dem Muskulus glu- 
taeus medius. Es wurden Biospien in Ruhe und 24 Stunden nach einem standardisierten Belastungstest, sowohl vor als auch nach Clenbuteroltherapie, entnommen. Clenbuterol wurde in einer Dosierung von $0,8 \mu \mathrm{g} / \mathrm{kg}$ zweimal täglich per oral verabreicht, wobei nach zwölf Tagen eine viertägige Medikationspause eingelegt wurde um eine Tachyphylaxie zu vermeiden.

Die Muskelproben wurden anhand verschiedener Färbemethoden (Hämatoxilin-Eosin, modifizierte Gomori-TrichromFärbung, Ölrot-Fettfärbung, saure Phosphatase-Färbung und PAS-Färbung) histologisch und histochemisch untersucht.

Nach der Clenbuterolbehandlung zeigte sich eine deutliche klinische Verbesserung bei den RAO-Pferden. Insbesondere die arteriellen Blutgaswerte waren deutlich verbessert (Abb. 1). Die histopathologischen Auswertungen der Muskelproben zeigten als Ergebnisse bei den RAO-Pferden eine erhöhte Variation der Muskelfaserdurchmesser (Abb. 2) und der mitochondrialen Aktivität (Abb. 3) im Vergleich zu den gesunden Kontrolltieren (Abb. 5). Bei zwölf Pferden, welche diese Veränderungen aufwiesen, zeigte sich in der Kontrolluntersuchung nach Clenbuterolverabreichung eine deutliche Reduktion der Befunde (Abb. 2 und 6). Somit konnte die Ausgangsthese dieser Studie, dass durch eine Verbesserung der Lungenfunktion nach medikamenteller Behandlung eine Reduktion der metabolischen Skelettmuskelveränderungen zu erreichen ist, bestätigt werden.

Die Untersuchung der Skelettmuskulatur vor und nach Belastung lieferte dagegen keine einheitlichen Ergebnisse. Somit konnte keine direkte Auswirkung einer standardisierten Belastung auf die mitochondriale Aktivität in dieser Studie nachgewiesen werden. 